\title{
GUILTY FEELING PADA SEORANG WANITA LESBIAN DI PALEMBANG
}

\author{
Anissa Siti Ri'ayah ${ }^{1}$, Dwi Hurriyati ${ }^{2}$ \\ Fakultas Psikologi, Universitas Bina Darma Palembang ${ }^{12}$ \\ Jalan A. Yani No.3 Palembang \\ Surel : annisasiti.asr@gmail.com ${ }^{1}$,dwi.hurriyati@binadarma.ac.id ${ }^{2}$
}

\begin{abstract}
This research aims to understand the factors that cause a lesbian woman to feel guilty feeling good with their parents, God created it later in themselves. The impact after they undergo as a lesbian woman and the expression of guilty feelings towards her family. And also what are the factors that cause a lesbian woman. The researcher used a qualitative research design and used a phenomenological approach to determine the factors that cause lesbian women to feel a guilty feeling. In this study, researchers used 2 research subjects and 4 people as sources of information. The results of this study found that the cause of the subject to feel guilty feeling was due to fear of punishment that would be given by God the creator and also did not want his late father to feel disappointed with what they had done and also did not want his mother to feel the sadness that the subject had done. Then also the subject realizes that what has been done is an untrue act that has violated the established norms and rules. This is the factor that causes lesbian women to feel a guilty feeling.
\end{abstract}

Keywords: Guilty feeling, Lesbi, guilty feeling factors

\begin{abstract}
Abstrak : Penelitian ini bertujuan untuk mengetahui faktor yang menyebabkan seseorang wanita lesbian merasakan adanya guilty feeling baik dengan orangtua,Tuhan yang menciptakannya kemudian pada diri mereka sendiri. Dampak setelah mereka menjalani sebagai wanita lesbian dan pengungkapan guilty feeling terhadap keluarganya. Dan juga apa saja faktor yang menyebabkan menjadi seorang wanita lesbian. Peneliti menggunakan desian penelitian kualitatif serta menggunakan pendekatan fenomenologi unuk dapat mengetahui faktor penyebab wanita lesbian meraskan adanya guilty feeling. Dalam penelitian ini,peneliti menggunakan 2 subjek penelitian dan 4 orang sebagai sumber informasi. Hasil penelitian ini menemukan bahwa penyebab subjek merasakan guilty feeling adalah karena takut akan hukuman yang akan diberikan Tuhan sang pencipta dan juga tidak mau almarhum ayahnya merasa kecewa atas apa yang telah mereka lakukan dan juga tidak mau ibunya merasakan kesedihan yang telah subjek lakukan. Kemudian juga subjek menyadari bahwa yang telah diperbuat adalah perbuatan yang tidaklah benar yang sudah melanggar norma-norma, aturan yang telah ditetapkan. Hal demikan yang menjadi faktor penyebab wanita lesbian merasakan adanya guilty feeling.
\end{abstract}

Kata kunci : Guilty feeling, Lesbi , Faktor penyebab

\section{PENDAHULUAN}

Seiring dengan perkembangan zaman

dan faktor pengaruh dari kebudayaan luar

dan juga dengan mudahnya orang asing

keluar masuk Indonesia,menyebabkan maraknya kehidupan pergaulan bebas dan muncul beberapa penyimpangan, salah satu bentuk dari penyimpangannya adalah penyimpangan seksual (Orientasi seksual)

salah satu contohnya yaiu homoseksual. Guilty feeling pada Seorang Wanita Lesbian ...... ( Anissa Siti Ri'ayah dan Dwi Hurriyati) 113 
Homoseksual di negara Indonesia merupakan hal yang masih tabu dan sulit untuk diterima dikalangan masyarakat.

Orientasi seksual merupakan istilah yang mengarah kepada jenis kelamin, yang ditandai dengan ketertarikan secara emosional, fisik, seksual dan cinta yang bertahan lama terhadap individu tersebut. Orientasi seksual terbagi tiga yaitu heteroseksual, homoseksual dan biseksual . Heteroseksual merujuk kepada ketertarikan terhadap jenis kelamin yang berbeda, sementara itu homoseksual merujuk kepada ketertarikan terhadap jenis kelamin yang sama dan biseksual merujuk kepada ketertarikan kepada kedua jenis kelamin. Heteroseksual disebut juga dengan istilah straight, sedangkan laki-laki homoseksual dikenal dengan istilah gay, dan perempuan homoseksual disebut dengan lesbian . Fenomena lesbian ini semakin marak di Indonesia, terutama di kota-kota besar. Di Indonesia sendiri, data statistik menyatakan bahwa 8 dari 10 juta populasi pria Indonesia pada suatu waktu pernah terlibat pengalaman homoseksual. Hasil survai YPKN (Yayasan Pendidikan Kartini Nusantara) menunjukkan, ada 4000 hingga 5000 penyuka sesama jenis di Jakarta. Sedangkan Gaya Nusantara memperkirakan, 260.000 dari enam juta penduduk Jawa Timur adalah homo. Angka-angka itu belum termasuk kaum homo di kota-kota besar lainnya (Gatra dalam Mutmainnah \& Ismi,2012)

Berdasarkan PPDGJ III (Sarwono dan Meinarno,2009) memaparkan pada umumnya, para penyandang homoseksualitas itu sendiri tidak mengetahui mengapa mereka menjadi demikian. Jadi keadaan tersebut bukan atas kemauan atau kehendak sendiri. Namun demikian, memang ada juga sebagian yang menerima keadaan dirinya dan hidup dengan senang sebagai homoseksual (egosintonik) dan ada sebagian yang tidak dapat menerima keadaan dirinya atau merasa dirinya tidak sesuai dengan norma- norma yang berlaku di dalam masyarakat, sehingga mereka-terus menerus berada dalam keadaan konflik batin selama hidupnya (egodistoni) golongan ini selalu menjadi pasien ataupun klien psikiater atau psikolog.

Homoseksual adalah orientasi dimana seseorang memiliki ketertarikan 3 seksual kepada jenis kelaminnya. Lesbian merupakan istilah untuk homoseks perempuan, gay untuk homoseks laki-laki, dan biseksual adalah orientasi seksual dimana seseorang memiliki ketertarikan baik kepada lawan jenis maupun sesama jenis (Saragih dan Irmawati, 2009).

Novyani (2017) Populasi gay di Indonesia sekarang sudah banyak. Sebuah survey menunjukkan yang dilakukan di kota besar Semarang. Menurutnya sampai dengan bulan Desember 2015 kaum lesbi Kota Semarang yang bergabung dalam Sobat Semarang adalah sebanyak 1.240 orang, 
mereka membuat akun facebook tertutup sebagai sarana berkomunikasi sesama anggota. Sedangkan yang terjangkau secara terang- terangan dan terbuka sebanyak 50 orang. Namun belum pernah dilakukan pencatatan secara lebih komprehensif dan baru mulai Januari 2015 melakukan pencatatan walau masih sangat sederhana dan meminta bantuan beberapa tokoh akademisi untuk menjadi dewan Penasehat. Kelompok usia lesbian di Semarang yang pernah di jumpai oleh Sobat Semarang bervariatif mulai dari SMP, SMA, Mahasiswa, maupun yang sudah bekerja. Sobat Semarang ini rutin mengadakan pertemuan kecil tiap satu minggu sekali untuk LGBT (Lesbian, Gay, Biseksual, dan Transgender) se-Semarang.

Lesbian merupakan istilah yang diambil dari sebuah Pulau Lesbos, yang dimana perempuan di pulau tersebut menyukai sesama jenis. Lesbian adalah perempuan yang memilih untuk mengikatkan dirinya secara personal (secara psikis, fisik, dan emosional) dengan sesama perempuan (Rohmawati, 2016).

Banyak faktor yang bisa mempengaruhi seorang menjadi lesbi bisa diantaranya ialah faktor biologis (kelainan otak\&saraf), faktor psikodinamika adanya gangguang seksual sejak masih anak-anak, faktor sosiocultural adanya adat-istiadat yang memberlakukan homoseksual dengan alasan yang tidak benar, kemudian terakhir adanya faktor lingkungan yang memungkinkan mendorong para pelaku menjalin cinta dengan erat.

Di dalam kelompok lesbi terdapat semacam label yang muncul karena dasar karakter atau penampilan yang terlihat pada seorang lesbi yaitu, Butch, Femme dan Andro. Istilah lesbi di bagi menjadi beberapa sebagai peran mereka akan jadi apa antaranya sebagai berikut: Butch (B) adalah lesbi berpenampilan tomboy, kelaki-lakian, lebih suka berpakaian laki-laki (kemeja laki-laki, celana panjang, dan potongan rambut sangat pendek). Femme (F) adalah lesbian yang berpenampilan feminim, lembut, layaknya perempuan heteroseksual biasanya, berpakaian gaun perempuan. Sedangkan Andro atau Androgyne (A) adalah perpaduan penampilan antara butch dan femme. Lesbi ini bersifat lebih fleksibel, artinya dia bisa saja bergaya tomboy tapi tidak kehilangan sifat feminimnya, tidak risih berdandan dan menggunanakan make up, menata rambut dengan gaya feminim, dan sebagainya. (Worthington\& Reynolds,2009). Besarnya angka insidensi dan angka prevalensi penyimpangan perilaku lesbian secara akurat memang sangat sulit. Penelitian yang dilakukan oleh banyak pakar dari banyak negara belum mampumenentukan secara tepat besarnya angka insidensi dan prevalensi lesbian. Namun, secara umum, 
diperkirakan jumlah kaum lesbian dan homoseksual didalam masyarakat adalah $1 \%$ hingga $10 \%$ dari jumlah populasi. Seorang ahli seksologi terkenal, Kinsey, bahkan menyebutkan bahwa setidaknya $2 \%$ hingga 5\% wanita adalah lesbian. Berdasarkan penelitian yang dilakukan Kinsey pada remaja berusia 20 tahun, terdapat $17 \%$ perempuan mempunyai pengalaman lesbian. Pada penelitian yang dilakukan terhadap remaja berusia 16-19 tahun, terdapat 6\% wanita lesbian. Ada pula pakar melaporkan bahwa 10,7\% murid SMA berusia 12-18 tahun tidak yakin dengan orientasi seksual mereka, sekitar 5-6\% dari murid-murid ini dideskripsikan sebagai lesbian (Soewandi, 2012).

Banyak sudah terjadi perluasan kasus tentang lesbian ini terutama juga terdapat di daerah Palembang. Dan disini peneliti memiliki dua subjek ,sebut saja namanya subjek pertama DS dan subjek kedua AQ . DS adalah wanita tomboy yang lulus sekolah pada tahun 2016 sekarang DS bekerja sebagai penjaga konter di daerah dekat dengan rumahnya ,DS sekarang berusia 21 tahun DS adalah anak ke lima dari enam bersaudara. Subjek kedua AQ adalah seorang perempuan cantik dan terlihat seperti perempuan lainnya dia berusia 21 tahun ,AQ bekerja disalah satu perusahaan swasta di Palembang.

\section{METODOLOGI PENELITIAN}

Penelitian ini menggunakan metode pendekatan kualitatif, dimana sebagian peneliti kualitatif berbicara tentang dunia kehidupan personal, dan mereka mencoba untuk menggambarkan pengalaman seorang individu didalam wilayah khusus yang penuh makna.

Penelitian ini dilakukan di kota palembang, dengan menggunakan model pedekatan studi fenomenalogi tentang faktorfaktor penyebab subjek mengalami guilty feeling dan dinamika psikologis guilty feeling pada seorang wanita lesbian. Dimana peneliti melakukan penelit iannya di taman tvri, tempat kerja subjek dan dirumah peneliti untuk melakukan interviewdanobservasi

Dalam penelitianini metode pemilihan sampel yang digunakan adalah non-random sampling/ non-probability sampling, yaitu metode sampling di mana setiap individu atau unit dari populasi tidak memiliki kemungkinan (non- probability)yang sama untuk terpilih. Ada pertimbanganpertimbangan tertentu yang mendasari pemilihan sampel. Biasanya pertimbanganpertimbangan tersebut disesuaikan dengan latar belakang fenomena yang diangkat dan tujuan penelitian (Herdiansyah,2015).

Koentjoro (2010) menyebut ada empat sumber data dalam penelitian kualitatif : subjek, informan pelaku dan informan 
tahu/tidak tahu, written document dan unwrittendocument.

Teknik yang digunakan dalam penelit ian ini adalah gabungan dari teknik observasi, wawancara dan dokumentasi. Penjelasan dari teknik- teknik yang digunakan dalam penelitian ini adalah:

\section{Observasi}

Herdiansyah (2015) mendefenisikan bahwa Observasi merupakan kumpulan data yang menggunakan alat indera. Dari difinisi tersebut dinyatakan bahwa obesrvasi merupakan metodepengumpulan data melalui indera manusia. Dalam suatu kondisi yang alami, observasi merupakan tindakan pengamatan fenomena sosial di dunia nyata dan juga merekam kejadian yang telah terjadi.

\section{Wawancara}

Dalam penelitian ini peneliti menggunakan metode wawancar dari Srewart dan Cash (Herdiansyah, 2015) mendefinisikan wawancara diartikan sebagai suatu interaksi yang didalamnya terdapat pertukaran atau sharing aturan, tanggung jawab, perasaan, kepercayaan, motif dan informasi.

\section{Menurut Smith (2009) pada} wawancara semi-terstruktur, peneliti merancang serangkaian pertanyaan yang disusun dalam satu daftar wawancara,akan tetapi daftar tersebut digunakan untuk menuntun dan bukan untuk mendikte wawancara tersebut. Wawancara semi- terstruktur memfasilitasi terbentuknya hubungan atau empati, memungkinkan keluwesan yang lebih besar dalam peliputan dan memungkinkan wawancara untuk memasuki daerah-daerah baru, dan cenderung untuk menghasilkan data yang lebih subur.

\section{Dokumentasi}

Dokumentasi ini pada umumnya digunakan sebagai instrumen tambahansaja yang bersifat memperkuat ataumenambah reliabilitas dari instrumen utama yaitu wawancara, observasi dan focus group.Para ahli penelitian kualitatif jarang sekali merekomendasikan penggunaan

\section{HASIL DAN PEMBAHASAN}

Gambaran mengenai guilty feeling pada seorang wanita lesbian yang ada di Palembang sesuai dengan hasil temuan peneiliti terhadap subjek. Berdasarkan hasil wawancara dan observasi yang dilakukan dengan subjek menunjukkan adanya faktor-faktor penyebab guilty feeling sebagai wanita lesbian dan juga aspek-aspek guilty feeling. dari proses wawancara yang dilakukan didapatkan tema yang mengarah pada faktor-faktor penyebab guilty feeling sebagai wanita lesbian dan cara wanita lesbian mengungkapkan guilty feeling kepada keluarganya.

Guilty feeling menurut Coleman (2010) dapat digolongkan menjadi dua aspek utama yaitu: Guilty feeling yang muncul dari hubungan pribadi Guilty feeling lebih mudah 
berkembang pada diri seseorang tergantung pada intimnya hubungan tersebut, serta muncul hampir tanpa terasa bahkan tanpa disengaja. Harapan serta rasa takut biasanya amat besar pada hubungan yang intim,dalam hubungan yang seperti itula seseorang cenderung untuk lebih cepat merasa bersalah bila orang tersebut mengecewakan orang terdekatnya.Guilty feeling yang berkaitan dengan peran didalam masyarakat Perasaan bersalah dapat dilihat kemunculannya dari adanya peran yang tidak sesuai atau yang tidak diharapkan oleh masyarakat. Peran tersebut dapat di generalisasikan pada peran-peran yang menyimpang terhadap norma,aturanaturan,etika serta moral yang menjadi suatu sistem penilaian berperilaku didalam masyarakat.

Seperti halnya subjek pertama DS upaya menghindari dari bahan perbincangan oleh keluarga besaranya karena mereka tahu bahwa dirinya adalah seorang lesbian dan untuk menjaga hati ibunya supaya tidak tersakiti mendengarkan perkataan kerabat-kerabatnya subjek DS memilih untuk tidak mengikuti acara kerbat-kerabatnya. Dan subjek juga mengatakan bahwa inilah mungkin hasil dari perbuatannya menjadi seorang wanita lesbian hal ini dapat dilihat dari tema kedua yang Menyatakan bahwa Subjek DS mengugkapkan bahwa dirinya merasa guilty feeling terhadap orang sekitarnya karena subjek memilih menjadi seorang lesbian orang-orang disekitarnya seperti kerabat,dan temantemannya menjauhinya dan dia juga merasa takut akan dikucilkan orang sekitarnya jika ia masih nekat ikut berkumpul dengan kerabatnya. DS tidak ingin keluarganya dan terkhusus ibunya dikucilkan dan merasakan malu karena dirinya menjadi seorang lesbian. Dan subjek DS memilih untuk tidak pernah mengikuti acara dari kerabat-kerabatnya karena takut dikucilkan dan DS tidak ingin melihat ibunya sedih lagi karena dirinya seorang lesbian. Kemudian dirinya dijauhkan oleh teman-teman normalnya dan hingga sekarang dirinya tidak berkomunikasih hanya untuk bertukar kabar.

Guilty Feeling muncul karena seorang individu telah melakukan tindakan yang salah atau melakukan kesalahan yang menurut dirinya dan lingkungannya tindakan tersebut tidak sesuai dengan moral dan norma (Hanyi Xu ,2011).Berdasarkan pernyataan subjek pertama DS ,untuk faktor-faktor penyebab subjek mengalami guilty feeling karena subjek DS pernah ketahuan orangtuanya menjadi seorang wanita lesbian bersama dengan pasangannya di tempat tongkorongan, orangtua dan keluarga mencari dirinya karena sudah berbulan-bulan tidak pulang kerumah. Disitu dirinya melihat orangtuanya menangis karena mengetahui bahwa dirinya adalah seorang wanita lesbian, subjek merasakan hancur dan sedih karena melihat ibunya menangis. Kemudian untuk 
pernyataan dari subjek kedua yaitu $A Q$ faktorfaktor penyebab subjek mengalami guilty feeling karena subjek takut akan hukuman yang akan diberikan oleh sang pencita kepada ayahnya yang sudah meninggal atas apa yang telah dilakukakn selama ini didunia,subjek tidak ingin membuat susah ayahnya yang berada di akhirat dan ingin mengurangi hukuman dari sang ayah tersebut. Hal ini juga dapat dilihat dari tema ketiga .Kedua subjek merasakan guilty feeling terhadap keluarga dan orangtuanya terutama untuk ayahnya yang sudah meninggalkan dirinya saat sedang membutuhkan dukungan dan perhatian. Kemudian subjek DS menjelaskan bahwa dirinya tidak sangguup untuk melihat ibunya menangis atas perbuatan yang telah dilakukannya. Subjek AQ juga memaparkan bahwa dirinya tidak ingin melihat ibunya mengetahui atas perbuatan dirinya selama ini. Kedua subjek DS dan AQ merasakan guilty feeling terhadap allah swt sang pecipta subjek merasa bahwa dirinya telah melanggar aturan yang telahh ditetapkan oleh Allah ,bukan hanya Guilty feeling terhadap orangtuanya dan Allah saja tetapi subjek menagalami guilty feeling terhadap dirinya sedniri subjek menganggap bahwa dirinya tidak mensyukuri atas apa yang telah diberikan tuhan kepadanya. Cohen dan George (Syahputra 2011) berpendapat bahwa Guilty Feeling berhubungan secara positif dan signifikan dengan religiusitas dan moral. Moral mencakup perasaan bersalah dan perasaan menyesal yang digambarkan sebagai ketidaknyamanan setelah melakukan pelanggaran. Subjek DS mengungkapkan bahwa dirinya tidak sanggup dan tidak memberanikan diri untuk mengucapkan permintaan maaf kepada ibunya terhadap apa yang telah dia lakukan tetapi DS mempunyai cara lain dan sebisa mungkin untuk bisa membahagiakan ibunya dan berusah untuk Mengevaluasi diri dari yang negatif menjadi positif. Untuk subjek AQ sendri pengungkapan guilty feeling terhadap keluarganya adalah dengan dirinya keluar dari dunia perlesbian dan menjadi waniita normal seutuhnya dan sekarang subjek AQ bekerja disalah sau perusahaan swasta di Palembang dan juga subjek AQ mengatakan bahwa dirinya sekarang bahagia bisa mendaftarkan dirinya menjadi mahasiswa untuk melanjutkan pendidikannya ke jenjang yang lebih tinggi. Seperti halnya didalam tema ke empat yaitu pengungkapan guilty feeling terhadap keluarganya. Kedua Subjek menjelaskan bahwa dirinya sebisa mungkin akan berubah dan tidak mengulanginya kembali tetapi tentunya subjek harus dibantu oleh orang lain yang akan menjadi pasangan hidupnya nanti, dan jika subjek pertama DS telah menemukan pasangan hidupnya subjek berupaya untuk selalu bertanggung jawab atas apa yang telah dipilihnya dan tidak akan mendatangi lagi 
tempat/tongkrongan yang dimana yang membuat dirinya menjadi seperti sekarang ini. Penjelasan diatas adalah faktor-faktor yang menyebabkan subjek mengalami guilty feeling sebagai seorang lesbi, dan bagaimana guilty feeling wanita lesbian dalam mengungkpakan kepada keluarganya.

\section{Temuan Penelitian}

Subjek pertama yaitu DS yang merupakan seorang wanita lesbian dengantipe butch yang berumur 21 tahun. DS sekarang bekerja di konter yang berada di daerah kediamannya di daerah Talang ratu Km 5. DS memiliki kepribadian tomboy yang berprilaku seperti laki- laki dan memiliki ketertarikan seksual kepada sesama jenis dan DS mulai menyukai ketertarikan sesama jenis setelah kelulusan Sekolah Menengah Kejuruan (SMK). DS dibesarkan di keluarga yang sederhana tingal dirumah yang telah dikontrak oleh ibunya dan ayahnya telah meninggal saat dia masih kecil, ibunya sendirilah yang menghidupkan dia dan saudara-saudara lainnya. DS memiliki 5 saudara 2 saudara lakilaki 2 saudara perempuan,. DS menjadi seorang lesbian dikarenakan dipengaruhi lingkungan teman-temannya, teman-teman dari DS kebanyakkan seorang lesbian dan awalnya DS tidak tertarik tetapi DS temanteman mengatakan bahwa dia ganteng bila menjadi peran laki-laki (butch) dan akhirnya dia mencoba untuk menjadi seorang lesbian, dan hingga sekarang DS menjalani kehidupannya sebagai seorang wanita lesbian. Tetapi saat DS menjalani kehidupannya sebagai seorang lesbian subjek DS kedapatan oleh orangtua dan keluarganya berada disalah satu tempat tongkrongan dirinya bersama teman-temannya disitu subjek melihat ibunya menangis dan subjek DS merasakan namanya guilty feeling terhadaporangtuanyadan Tuhannya.Dirinya merasakan kesedihan yang mendalam ketika melihat ibunya menangis dan juga subjek merasakan guilty feeling terhadap almarhum ayahnya, subjek DS pun juga mengetahui bahwa yang dilakukannya adalah perbuatan dosa besar yang dilarang oleh Allah swt sebagai sang pecipta. Bukan hanya kepada orangtua,keluarga dan Tuhannya subjek pun merasakan guilty feeling yang mendalam kepada dirinya sendiri dan berpikir kenapa subjek bisa melakukannya sejauh ini, dan subjek juga merasakanguilty feeling terhadap teman-teman heterokseksualnya karena dirinya lebih memilih menjadi wanita lesbian dan menyalahkan aturan norma yang telah berlaku.

Subjek kedua yaitu AQ merupakan seorang wanita lesbian dengan tipe femme yang berusia 21 tahun. AQ merupakan wanita feminim yang berpenampilan dan bergaya seperti wanita normal pada umumnya. AQ memutuskan menjadiwanita lesbian sejak AQ 
tidak berhubungan lagi dengan pacarnya seorang laki-laki dan juga karena hal lain yang harus memaksakan dia menjadi seorang wanita lesbian. Hal lain yang memaksanya yaitu faktor ekonomi keluarganya yang menurun dikarenakan kepala keluarganya pergi meninggalkannya untuk selam-lamanyadan AQ tidak bisa lagi mendapatkan uang saku seperti biasanya, dan pasangan lesbian AQ ini memberikan semua yang dia inginkan. Kegiatan AQ adalah seorag karyawati perusahaan swasta Palembang. AQ adalah anak ke 2 dari 2 bersaudara dia memiliki kakak laki- laki. Ayah dari AQ telah meninggal ketika AQ duduk di bangku SMA kelas 3. AQ dan keluarganya tinggal di daerah talang betutu perumahan AU. Subjek kedua AQ merasakan guilty feeling yang teramat besar yaitu dengan almarhum ayahnya dan subjek juga tidak menyadari bahwa dirinya telah menjadi seorang wanita lesbian, AQ menjadi seorang lesbian lantaran dirinya tidak pernah diberikan perhatian khusus dari sang ibu dan saudara laki-lakinya setelah ayahnya telah meninggal, AQ pun tak jarang bahkan tidak pernah diberikan uang saku untuk dirinya itulah yang membuat dirinya menjadi seorang wanita lesbian karena pasangan dari AQ memiliki banyak uang dan selalu memberikan perhatian baik moral maupun mental kepada dirinya.Subjek AQ mengaku kepada peneliti bahwanya dirinya sangat terpukul sekali ketika dirinya telah jauh dari ayahnya yang selalu memberikan dirinya support dan memberikan perhatian penuh kepada dirinya, setelah menjalani menjadi seorang wanita lesbian subjek AQ tersadar dan merasakan bahwa dirinya telah salah memilih jalan untuk menjadi seorang wanita lesbian dan memilih untuk menjadi wanita normal seutuhnya. Subjek AQ pun takut bila ibunya dan saudara laki-lakinya sampai mengetahuinya walaupun ibunya tidak mengetahui tetapi dirinya sangat merasakan guilty feeling terhadap ibunya karena dirinya menjadiwanita lesbian, dan juga subjek merasakan guilty feeling yang amat besar kepada Allah swt sang pencipta dia takut akan hukuman yang akan diberikan oleh Allah dan sekarang subjek memlih untuk berubah sepenuhya menjadi seorang wanita normal dan juga subjek mengakui bahwa dirinya dibantu oleh teman heterokseksualnya. Gambaran mengenai guilty feeling pada seorang wanita lesbian yang ada di Palembang sesuai dengan hasil temuan peneiliti terhadap subjek. Berdasarkan hasil wawancara dan observasi yangdilakukan dengan subjek menunjukkan adanya faktor-faktor penyebab guilty feeling sebagai wanita lesbian dan juga aspek-aspek guiltyfeeling. dari proses wawancara yang dilakukan didapatkan tema yang mengarah pada faktor- faktor penyebab guilty feeling sebagai wanita lesbian dan cara wanita lesbian 
mengungkapkan guilty feeling kepada keluarganya.

\section{Guilty feeling menurut Coleman} (2010) dapat digolongkan menjadi dua aspek utama yaitu: Guilty feeling yang muncul dari hubungan pribadi Guilty feeling lebih mudah berkembang pada diri seseorang tergantung pada intimnya hubungan tersebut, serta muncul hampir tanpa terasa bahkan tanpa disengaja. Harapan serta rasa takut biasanya amat besar pada hubungan yang intim,dalam hubungan yang seperti itula seseorang cenderung untuk lebih cepat merasa bersalah bila orang tersebut mengecewakan orang terdekatnya.Guilty feeling yang berkaitan dengan peran didalam masyarakat Perasaan bersalah dapat dilihat kemunculannya dari adanya peran yang tidak sesuai atau yang tidak diharapkan oleh masyarakat. Peran tersebut dapat di generalisasikan pada peranperan yangmenyimpang terhadap norma,aturan-aturan,etikaserta moralyang menjadi suatu sistem penilaian berperilaku didalam masyarakat.

\section{SIMPULAN}

Berdasarkan uraian dan pembahasan, maka dapat ditarik kesimpulan bahwa subjek dalam penelitin ini mengalami guilty feeling terhadap Tuhan, orangtua, dan dirinya sendiri dan mereka memilih jalan hidup sebagai wanita lesbian adalah atas pilihan yang berasal dalam diri mereka sendiri. Kedua subjek menyadari bahwa mereka melakukan normanorma dan aturan yang salah, kedua subjek pun juga menyadari bahwa perbuatan mereka adalah perbuatan yang salah dan dilarang oleh Agama khusunya Agama Islam sendiri. Kedua subjek menjalani masa lesbian sudah dari tahun 2016 saat mereka lulus sekolah dan juga memiliki faktor yang sama yaitu ditinggalkan ayahnya meninggal dunia dan juga karena faktor lingkungan pertemanan mereka.

Kedua subjek sangat ingin sekali untuk berubah menjadi yang lebih baik tetapi subjek DS selalu dipengaruhi oeh lingkungan yang membuat susah untuk berubah. Kedua subjek sama-sama tidak memberanikan diri untuk mengungkapkan bahwa mereka adalah seorang lesbi kepada keluarganya. perbedaan kedua subjek yaitu mengalami dampak setelah menjadi seorang lesbian disini hanya subjek DS yang menjelaskan bahwa dirinya memiliki dampak setelah menjadi seorang wanita lesbian subjek DS dijauhkan teman-teman normalnya untuk bertukar kabar pun mereka tidak, itulah yang membuat subjek menyadari bahwa itulah resiko ketika kita memilih keputusan yang salah.

Faktor penyebab guilty feeling, kedua subjek memiliki persamaan, persamaannya yaitu merasakan guilty feeling terhadap Allah sang pencipta dan kemudian terhadap orangtuanya khususnya kepada ayah yang telah meninggalkan mereka dan kedua subjek mengakui jika ayahnya tidak meninggalkan mereka , kedua subjek tidak akan mengalami atau menjadi seorang lesbian seperti sekarang. 
Kemudian faktor guilty feeling terhadap masyarakat atau kerabat subjek, kedua subjek tidak merasakan guilty feeling terhadap masyarakt dan kerabatnya karena subjek menganggap mereka tidak memberikan dirinya makan untuk hidup tetapi yang ditakutkan oleh subjek adalah ibunyaa menjadi sakit hati ketika berkumpul dirinya menjadi bahan perbincangan kerabatnya.

Kedua subjek dalam penelitian ini memiliki karakter dan tipe yang berbeda dimana subjek yang pertama memiliki karakter seperti laki-laki subjek pertama bergaya tomboy yang memakai atribut laki-laki yang disebut dengan butch, kemudian yang kedua memiliki karakter dan tipe lesbian seperti perempuan heteroksesual pada umumnya ,subjek bersolek mempercantik diri dan memakai semua atribut perempuan karakter ini disebut dengan femme. 


\section{DAFTAR RUJUKAN}

Coleman, Vernon. 2010. Rasa Salah Mengapa Terjadi, Bagaimana Mengatasinya. Jakarta: Arcan.

Herdiansyah, H. (2015). Metodologi Penelitian Kualitatif Untuk Ilmu Psikologi. Jakarta: Salemba Humanika

Koentjoro. 2010. Metode Penelitian Kualitatif untuk Ilmu-Ilmu Sosial. Jakarta: Salemba Humanika.

Mutmainnah, M.B. \& Ismi. (2012). Perilaku Komunikasi Antarpribadi Pasangan Gay Di Kota Makassar. Skripsi. Makassar : Universitas Hasanuddin

Noviyani, D. (2017).Perilaku seksual berisiko infeksi menular seksua(IMS) pada kelompok lesbi di kota Semarang .Jurnal of Health Education.

Saragih, J. I. \& Irmawati. (2005). Fenomena Jatuh Cinta Pada Mahasiswi. Psikologia.Vol I. No I. Sumatera Utara : PS. Psikologi Fakultas Kedokteran Universitas Sumatera Utara.

Sarwono, S. W., \& Meinarno, E. A. (2009). Psikologi Sosial. Jakarta : Salemba Humanika

Soeawandi, H., (2012). Lesbian dalam Pandangan Psikiatrik. KOMPAS, 14 Juni 2010.

Worthington, R. L., \& Reynolds, A. L. (2009). Within-Group Differences in Sexual Orientation and Identity. Journal of Counseling Psychology. Vol. 56, No. $1,44-55$ 